\title{
«Vi leker ikke teater!» Larerfellesskapet i valgfaget produksjon for scene som profesjonelt kunnskapslandskap
}

\author{
Solveig Salthammer Kolaas \\ Nord universitet, Norge
}

\begin{abstract}
Sammendrag
Denne artikkelen undersøker fire ungdomsskolelæreres arbeid i og med valgfaget produksjon for scene. Fokus er på hvordan læreres praksis og kompetanse samvirker og til sammen danner en kollektiv praksis i form av et profesjonelt kunnskapslandskap. Datamaterialet for artikkelen består av intervju med fire lærere og observasjoner av deres arbeid i en musikkteaterproduksjon i faget skoleåret 2017/2018. Artikkelen har et hermeneutisk vitenskapsteoretisk perspektiv og er informert av narrativ analyse. Hver av de fire lærernes praksis analyseres og presenteres gjennom fire narrativ. Narrativene settes videre i dialog med hverandre og fordypes gjennom Kemmis et al. (2014) sin teori om praksisarkitekturer. Oppdagelser i studien gir innsikt i hvordan lærernes individuelle praksis formes av den kunstfaglige ekspertisen de har med seg fra det profesjonelle og frivillige kunst- og kulturfeltet utenfor skolen, og hvordan disse praksisene videre skaper en kollektiv praksis der grunnforståelsen er fokus på profesjonalitet og kvalitet i det kunstfaglige arbeidet, og pedagogisk tenkning om fellesskap og mestring.
\end{abstract}

Nøkkelord: samkunstlig prosjektarbeid $i$ skolen; sceneproduksjon; lcerersamarbeid; profesjonelt kunnskapslandskap; musikkteater

Recieved: November, 2020; Accepted: March, 2021; Published: May, 2021

\begin{abstract}
"Theatre for real!" Teacher collaboration as a professional knowledge landscape in the lower secondary school elective subject stage production

This article examines the work of four lower secondary school teachers in the field of the elective subject "stage production", focusing on how teachers' practices and competences interact and together create a professional knowledge landscape as their collective practice. The data material consists of teacher interviews and observations regarding their work with a musical theatre production in the year 2017/2018. The article has a hermeneutic perspective and is informed by narrative analysis. The four teachers' practices are analysed and presented through four narratives. The narratives are further discussed in light of each other and Kemmis et al.'s (2014) theory of practice
\end{abstract}

\footnotetext{
^Korrespondanse: Solveig Salthammer Kolaas, e-post: solveig.s.kolaas@nord.no

(C) 2021 S. S. Kolaas. This is an Open Access article distributed under the terms of the Creative Commons Attribution 4.0 International License (https://creativecommons.org/licenses/by-nc/4.0/), allowing third parties to copy and redistribute the material in any medium or format and to remix, transform, and build upon the material for any purpose, even commercially, provided the original work is properly cited and states its license. 


\section{S. S. Kolaas}

architectures. Findings in the study provide insights into how the teachers' individual practices are shaped by their artistic expertise from the professional and voluntary performing arts outside of school, and further how these practices create a collective practice, where the basic idea is the focus on professionalism and quality in the work of arts, as well as pedagogical thinking about fellowship and mastery.

Keywords: co-art projects in school; stage production; teacher collaboration; professional knowledge landscape; musical theatre

\section{Innledning}

Mens læreryrket tidligere i stor grad ble definert gjennom lærernes selvstendige yrkesutøvelse i rollen som enehersker i klasserommet (Hargreaves, 2000), utfordres dette bildet i dag av at mer samarbeid og kollektive dimensjoner har kommet i forgrunnen (Elstad et al., 2014). I 2020 ble fagfornyelsen av Kunnskapsløftet (LK20) innført i Norge (Kunnskapsdepartementet, 2017). Nye læreplaner gir retning for innhold og arbeidsformer i de ulike fagene, og videre for lærernes profesjon. Den overordnede delen i LK20 gir føringer for mer tverrfaglighet, praktiske arbeidsformer og mer tid til fordypning (Kunnskapsdepartementet, 2017, 2019). Denne artikkelen handler om valgfaget produksjon for scene ${ }^{1}$ (Utdanningsdirektoratet, 2020), som jeg omtaler gjennom begrepet samkunstlig. Produksjon for scene omfatter fagområder som for eksempel musikk, dans, drama og kunst og håndverk, og betegnelsen samkunstlig rommer aktiv samhandling både mellom de ulike kunstfagene og mellom aktørene som deltar i produksjonene (Kolaas \& Angelo, 2021). Et fag som produksjon for scene kan i kraft av sin samkunstlighet inspirere til nye arbeidsformer og læringsfellesskap både for lærere og elever, og i arbeidet med sceneproduksjon kan ulike praksiser og kompetanseområder møtes. Kunnskap om hvordan ulike lærerpraksiser samvirker i samkunstlig prosjektarbeid i skolen er relevant både med tanke på lærersamarbeid, skolen som læringsarena og for lærerutdanningsfeltet.

Dette er bakgrunnen for at jeg i denne artikkelen undersøker: Hvordan skaper fire individuelle lererpraksiser til sammen én kollektiv praksis $i$ form av et profesjonelt kunnskapslandskap $i$ valgfaget produksjon for scene? Jeg besvarer problemstillingen gjennom først å analysere hver av de fire lærernes praksis og presentere dem gjennom fire narrativ (Riessman, 2005). Videre diskuterer jeg narrativene i lys av hverandre og teori om praksisarkitekturer (Kemmis et al., 2014) for å utvikle innsikt i hvordan de fire individuelle lærerpraksisene til sammen danner en kollektiv praksis $i$ form av et profesjonelt kunnskapslandskap (Craig, 2007).

\footnotetext{
${ }^{1}$ Faget artikkelen handler om har endret navn mens studien har pågått. Artikkelen utgis etter at fagets navn har blitt produksjon for scene, mens datamaterialet ble generert mens faget het sal og scene. Med tanke på leservennlighet og aktualitet har jeg valgt å gjennomgående bruke navnet produksjon for scene i artikkelen, også når det gjelder henvisninger til datamaterialet, selv om faget het sal og scene da feltarbeidet pågikk i skoleåret 2017/2018.
} 
Artikkelen legger vekt på lærersamarbeid i samkunstlig eller tverrkunstfaglig prosjektarbeid i skolen. Søk i databaser som Oria og Idunn viser at det finnes forskning og litteratur både om lærersamarbeid, tverrfaglig og kunstfaglig arbeid relatert til profesjonelle kunnskapslandskap (Craig, 2007; Emstad \& Birkeland, 2020; Helstad, 2014; Østern, 2018) og om profesjonsutvikling i skolen (Elstad et al., 2014; Hargreaves, 2000) som er relevant for denne studien. Om kunstfaglig arbeid i skolen finner jeg litteratur om kunstfaglærerprofesjonen (Angelo, 2014), kreative prosesser, estetisk læring og dybdelæring (Ross, 1978; Sørensen \& Austring, 2010; Østern et al., 2019). Jeg finner også relevant litteratur om skolemusikal (Bobetsky, 2008; Edberg, 2013, 2019), men med unntak av en masteroppgave om faget sal og scene (Rønning, 2019) har jeg ikke funnet forskning om selve faget produksjon for scene. Denne artikkelen er et kunnskapsbidrag både til eksisterende forskning om lærersamarbeid i tverrfaglig arbeid i skolen og til skolen som arena for fordypning, tverrfaglighet og praktisk arbeid. I tillegg er den et kunnskapsbidrag om estetiske fag i skolen generelt, og spesifikt om faget produksjon for scene realisert som musikkteaterproduksjon.

Jeg vil nå gi et innblikk i valgfaget produksjon for scene, først ved å presentere hovedelementene i læreplanen, for så å beskrive hvordan faget er organisert ved studiens deltakerskole.

\section{Læreplan i valgfaget produksjon for scene}

I læreplanen for produksjon for scene står det at elevene skal «få erfaring med de ulike delene i en scenisk produksjon, fra planlegging til ferdig produkt» og at faget omfatter tre kjerneelementer: scenisk produksjon, kunstnerisk formidling og identitet i skapende fellesskap (Utdanningsdirektoratet, 2020). Det første kjerneelementet omfatter produksjonsprosessen fra idé til produksjon. Det andre omfatter den kunstneriske formidlingen i og av sceneproduksjonen, og det tredje handler om å utfordre seg selv i skapende fellesskap. Læreplanen er åpen og legger få konkrete føringer for innholdet i faget og for hvordan faget skal gjennomføres. Dette åpner for kunnskapsområder som ikke er egne fag i grunnskolen, for eksempel drama, teater og dans. Ved skolen der jeg har generert min empiri har lærerne valgt å realisere faget gjennom å produsere én musikkteaterforestilling eller musikal per år. Empirien artikkelen bygger på viser at valget av musikkteater eller musikal som sjanger henger sammen med de involverte lærernes interessefelt og kompetansebakgrunn. Denne sammenhengen kommer også fram i en evalueringsrapport om valgfagene i skolen, som viser en tendens til at operasjonaliseringen av valgfagene ved de ulike skolene gjenspeiler lærernes interesser og kompetanse (Dæhlen \& Eriksen, 2015). Denne tendensen synliggiøres også i en landsomfattende spørreskjemaundersøkelse fra 2019, som viser at faget sal og scene (nå produksjon for scene) i stor grad framstår som et musikk- og teaterfag, og at dette kan ha en sammenheng med lærernes formelle og uformelle kunstfaglige kompetansebakgrunn (Kolaas \& Knigge, under utgivelse). Deltakerskolen i denne studien kan dermed stå som et eksempel på dette. 
Med bakgrunn i datamaterialet vil jeg videre beskrive hvordan faget produksjon for scene gjennomføres ved deltakerskolen, her kalt Lillenes ungdomsskole. Navnene på skolen, lærerne og elever er fiktive av hensyn til personvern. Studien er meldt inn til NSD, og samtykkeerklæring er undertegnet av alle forskningsdeltakerne. For å skape en troverdig studie er member checking (Stake, 1995) gjennomført i form av at lærerne har lest gjennom artikkelen og bekreftet at de kjenner seg igjen i de beskrivelsene og tolkningene jeg som forsker har gjort i arbeidet med materialet.

\section{Produksjon for scene ved Lillenes ungdomsskole}

Lillenes ungdomsskole har ca. 450 elever og 60 ansatte. Første sceneproduksjon i faget ble gjennomført skoleåret 2013/2014. Tre av musikklærerne ved skolen, Ingse, Siri og Frode, fikk da ansvar for arbeidet med å utvikle det nye valgfaget sal og scene, som ble innført i skolen i 2012 (Utdanningsdirektoratet, 2012b). Musikkteater eller musikal ble valgt som fast produksjonsform, noe som synes å ha sammenheng med lærernes erfaringsbakgrunn. Alle de tre lærerne har utdanning som grunnskolelærere og har kompetanse og erfaring fra ulike scenekunstfag: Frode har bakgrunn fra amatørmusikklivet gjennom korps og band, mens Ingse og Siri har utdanning i drama og musikk og har bred erfaring fra amatørteater. Ingse jobber også som profesjonell skuespiller og sanger og Siri har erfaring fra amatørteater, både med administrativt arbeid og som skuespiller. I 2015 ble lærerteamet utvidet med en fjerde lærer, Torhild. Torhild har eget atelier og arbeider som kunstner innen maling, glasskunst, keramikk, søm, design og redesign. Hun er utdannet fotograf og har 90 studiepoeng i kunst og håndverk. I tillegg har hun erfaring med kostymearbeid fra amatørteater og har vært på flere profesjonelle kurs i kostymedesign.

For lærerne ved Lillenes skole starter arbeidet med neste års musikkteaterproduksjon umiddelbart etter at inneværende års forestillingsperiode er over. Da klargjør de manus og musikk slik at elevene kan starte arbeidet med årets produksjon ved skolestart. Sminke- og kostymegruppa består av elever fra åttende trinn, og scenegruppa av elever fra 9. og 10. trinn. Elevene i scenegruppa får selv velge om de vil være musikere, skuespillere, lys/lydteknikere eller scenearbeidere, og fordeling av de ulike rollene gjøres gjennom audition. Før jul organiseres arbeidet som to skoletimer per uke, der elevene i hovedsak jobber gruppevis: Musikerne øver inn musikken, skuespillerne jobber med regi, koreografi og sang, og kostymegruppa arbeider med å designe og sy kostymer. Etter jul settes sang, musikk, skuespill, koreografi, kostymer, sminke, lys og lyd sammen til en helhetlig musikkteaterforestilling. De siste tre helgene før premiere er det fellesøvinger, og hele uka før premiere er det heldagsøvinger.

De fire lærerne har tydelig definerte ansvarsområder. Siri er produksjonsleder med overordnet ansvar for økonomi, søknadsskriving og praktisk organisering. Ingse er sanginstruktør og regissør med overordnet kunstnerisk ansvar for sceneproduksjonen, Frode er musikkansvarlig og Torhild har ansvaret for kostyme og sminke. Lyssetting gjøres av elever ved skolen, mens kompetanse på lyd og koreografi leies inn fra profesjonelle aktører. Scenografien skaper lærerne i fellesskap. I 2015 opprettet 
de fire lærerne et eget frittstående teaterlag, her kalt Stjernesol, og meldte dette inn i Norges største teaterorganisasjon, Frilynt. ${ }^{2}$ Gjennom støtteordninger i Frilynt benytter lærerne seg av kurs i blant annet sminke, teatersport og scenografi, de får konkret hjelp og veiledning med scenografi og de får låne kulisser og kostymer. Gjennom Frilynt får de også økonomisk støtte. Andre inntektskilder til produksjonsarbeidet er sponsor- og billettinntekter. I tillegg utbetaler skolen et ekstra honorar til lærerne som en kompensasjon for tid som brukes ut over ordinær undervisningsressurs.

Lærerne inviterer til samarbeid mellom hjem og skole, og med andre fag ved skolen. De har utformet en kontrakt der elevene forplikter seg til oppmøte på øving ut over ordinær skoletid. Både elever og foreldre må skrive under kontrakten før arbeidet med produksjonen starter. Ved oppstart arrangerer lærerne et informasjonsmøte, der foreldrene informeres om årets oppsetning og inviteres til frivillig dugnad i form av vakthold og matservering i forbindelse med forestillingene og helgeøvingene. Andre valgfag ved skolen er involvert i forestillingsperioden, for eksempel produksjon av varer og tjenester (Utdanningsdirektoratet, 2012a) som står for kaffe- og kakesalg. Rektor og ledelsen ved skolen er sterkt involvert i arbeidet, og deltar jevnlig på møter med lærerteamet.

\section{Teori om praksisarkitekturer}

Som teoretisk rammeverk i artikkelen bruker jeg Kemmis et al. (2014) sin teori om praksisarkitekturer. Denne utdanningsteorien søker innsikt i hvordan ulike praksiser kan forstås og defineres gjennom forhold som muliggjør eller begrenser disse (Kemmis et al., 2014, s. 31). En praksis er ifølge Kemmis et al. komponert av ytringer - det som sies, handlinger - det som gjøres, og relasjoner - måten mennesker relaterer seg til hverandre og verden rundt på (2014, s. 3). I denne artikkelen operasjonaliseres disse tre aspektene til det de ulike lærerne sier om og i sin egen praksis, de konkrete handlinger de gjør, og måten de relaterer til hverandre, kolleger, ledelsen og samfunnet forøvrig på. Forholdene som omgir en praksis omtales av Kemmis et al. som kulturell-diskursive, materiell-økonomiske og sosial-politiske, og utgjør de ressursene som muliggjør praksisens ytringer, handlinger og relasjoner (2014, s. 32). Prosessene som utgjør selve praksisen foregår i sosiale rom som oppstår mellom disse forholdene og praksisens ytringer, handlinger og relasjoner, og kommer til uttrykk gjennom medier som språk, rom og tid og sosiale forhold (Kemmis et al., 2014, s. 32). I denne studien konkretiseres de kulturell-diskursive forholdene, som den kunstfaglige kompetansen lærerne har med seg inn i sin lærerprofesjon. De materiell-økonomiske forholdene forstås her som de materielle og økonomiske rammefaktorene som ligger til grunn for arbeidet med faget. De sosial-politiske forholdene forstås som de sosiale forholdene mellom elever, lærere og ledelse på arbeidsplassen, og relasjonen til det profesjonelle og frivillige kulturlivet utenfor skolen.

\footnotetext{
${ }^{2}$ https://frilynt.no/om-frilynt/
} 
Begrepet profesjonelt kunnskapslandskap er tidligere brukt i utdanningsforskning, pedagogisk forskning og kunstbasert forskning både nasjonalt og internasjonalt (Clandinin, 2015; Craig, 2007; Emstad \& Birkeland, 2020; Helstad, 2014; Østern, 2018). I denne artikkelen bruker jeg ikke dette begrepet som en teoretisk inngang, men som en betegnelse på den kollektive lærerpraksisen lærerne til sammen utvikler. Min bruk av begrepet er motivert av Craigs (2007) definisjon (s. 175): som et bilde på et rom der de fire lærernes ulike praksiser samvirker til en meningsfull enhet, både mellommenneskelig og faglig, skapt av relasjoner mellom mennesker og fysiske rammefaktorer.

\section{Metode}

Kasusstudie, intervju og observasjon

På et metodologisk nivå undersøker kasusstudier konkrete eksempler innenfor et felt. Denne formen for kunnskapsgenerering knyttes ifølge Flyvbjerg (2010) nært opp til det virkelige liv gjennom kontekstuell og praktisk erfaring, noe han anser som selve kjernen i kasusstudier (s. 466). Deltakerskolen i denne studien er strategisk valgt ut med bakgrunn i min kjennskap til at skolen gjennom mange år har lagt ned mye arbeid i faget, og at produksjon for scene er et prioritert fag ved skolen. I studien har jeg fulgt fire lærere og 57 elever i deres arbeid med en musikkteaterproduksjon, fra start til ferdig forestilling. Det er vesentlig å framheve at den høye kompetansen og lærertettheten som kan ses som selvsagt ved deltakerskolen i denne studien, nok ikke er representativt for skoler i Norge i dag (Kolaas \& Knigge, under utgivelse). Studien kan likevel bidra til verdifull kunnskap, jamfør Flyvbjergs (2010) idé om at det kun er gjennom erfaring med enkelttilfeller at man kan bevege seg fra begynner- til ekspertstadiet (s. 466).

Empirien jeg genererte består av intervju og observasjon: fem halvstrukturerte individuelle intervju (Kvale \& Brinkmann, 2015) med de fire lærerne, fire observasjoner (Postholm, 2010) av lærermøter og sju av undervisningssituasjoner, både felles og i grupper. Intervjuene ble gjennomført med et åpent introduksjonsspørsmål om lærernes tanker om deres arbeid i faget. Videre fulgte oppfølgingsspørsmål, der mitt mål som forsker var å lytte aktivt til hva lærerne var opptatt av og å følge tematikken i samtalene videre i den retning. Intervjuene er dokumentert med lydopptak, og jeg har selv transkribert dem til tekst, med hovedfokus på innhold (Kvale \& Brinkmann, 2015). Denne måten å transkribere på begrunnes med tanke på det videre analysearbeidet, der fokuset først og fremst har vært på hva hver enkelt lærer var opptatt av i sin praksis. Min rolle som forsker i observasjonene har vært som fullstendig observatør, i betydningen observatør fra sidelinjen samtidig som jeg var til stede i rommet der handlingene foregikk (Postholm, 2010). Dette ble forskningsdeltakerne informert om på forhånd. I observasjonene var oppmerksomheten rettet mot lærerne og deres rolle i konteksten og situasjonene de var en del av. Som redskap til denne datagenereringen har jeg benyttet feltnotater og refleksjonslogg (Postholm, 2010). 


\section{Fra temaer til narrativ}

Min analytiske tilnærming $\mathrm{i}$ artikkelen er med et hermeneutisk blikk informert av narrativ analyse (Josselson, 2011; Riessman, 2005, 2008). Spor fra det hermeneutiske perspektivet handler om helhetsforståelse og tolkning av de fenomenene jeg undersøker, der analysen går fra rike beskrivelser til fortettet mening (Kvale \& Brinkmann, 2015). For eksempel beskriver en av lærerne på ulike måter betydningen av at elevene opplever å lykkes og å mestre oppgavene de får i arbeidet med sceneproduksjonen, noe jeg samlet har fortettet til meningsenheten mestring. Meningsenhetene kaller jeg temaer. Narrativ analyse refererer til en familie av kvalitative metoder som handler om å skape eller undersøke tekster i historiebasert form. Riessman (2005) omtaler tre typer narrativ analyse: tematisk, strukturell og dialogisk (interactional) analyse (s. 4). I artikkelen analyserer jeg hovedsakelig tematisk, med vekt på historiens innhold i betydningen hva lærerne sier eller gjør. Den strukturelle måten å analysere på synliggjøres gjennom min interesse for hvordan fortellingene fortelles, og dialogisk analyse eksemplifiseres i diskusjonen, der jeg diskuterer lærernes narrativer i dialog med hverandre, og med teori. Ifølge Josselson (2011) legger den narrative tilnærmingen vekt på nøkkelhendelser og følgende fire prinsipper: 1) helhetslesing for å få overblikk over struktur og sentrale tema, 2) lesing av de ulike delene, 3) gjentagende lesing for å finne hovedessensen i materialet og 4) diskusjon med utgangspunkt i teori (Josselson, 2011, s. 228). Min analyseprosess er inspirert av disse fire stegene og Riessmans (2005) tre typer analyse. Jeg gjennomførte først en helhetslesing for å få overblikk over materialet. Videre leste jeg de ulike delene hver for seg, både intervju og observasjoner, og gjorde en tematisk og strukturell analyse ut fra det hver enkelt lærer fortalte om egen praksis. Resultatet av dette arbeidet presenterer jeg gjennom fire narrativer, der hvert narrativ tenkes å framstille grunnforståelsen i hver enkelt lærers praksis slik jeg som forsker har forstått den i samspill med empirien. Til slutt diskuterer jeg narrativene i dialog med hverandre (Riessman, 2005) og i lys av teori om praksisarkitekturer (Kemmis et al., 2014).

Etter gjentatte gjennomlesninger av intervjuene, identifiserte jeg sentrale temaer de ulike lærerne omtalte. For eksempel fant jeg at Ingse var opptatt av kompetanse, profesjonalitet, mestring og lererrollen, og Frode av elevmedvirkning, fellesskap og mestring, lererrollen, forventninger og krav og kompetanse. Sentrale temaer jeg fant i Siris refleksjoner var trygge organisatoriske rammer, ledelsens involvering og fagets status og forankring $i$ kollegiet, mens Torhild var opptatt av elevenes kreativitet og skaperevne, elevenes eierforhold til kostymene og respekt for hverandres kompetanse. Eksempel fra intervju med Torhild som ledet meg fram til respekt for hverandres kompetanse, er:

Jeg er så glad for at Ingse er den hun er. Og Siri er så flink. Og Frode ikke minst. Ja altså, vi lærerne er veldig flinke til å rose hverandre for den jobben vi gjør. Vi møtes jo mye. Har møte en gang i uka og mange spørsmål, på Messenger, fram og tilbake om ulike ting. (Intervju med Torhild)

Siri var opptatt av ledelsens betydning for lærernes arbeid med faget. Eksempel fra intervju med Siri som ledet meg fram til temaet ledelsens involvering, er: 
Det har alt å si. For hvis vi ikke hadde hatt den ledelsen vi har, så hadde vi ikke fått det til.Vi hadde aldri klart å få til dette alene som lærere uten ledelsen i ryggen. Det hadde ikke vært mulig. (Intervju med Siri)

Neste steg i analysearbeidet var å redusere antallet temaer for å forstå essensen og grunnforståelsen i hver av lærerpraksisene. Gjennom strukturell analyse (Riessman, 2005) søkte jeg etter hvordan lærerne snakket om de ulike temaene. Intensivitet, engasjement, stemmebruk og flyt i praten er elementer jeg vektla i denne identifiseringen. For eksempel var det tydelig for meg at intensiviteten og engasjementet i stemmen til Ingse steg betraktelig når hun snakket om temaet profesjonalitet, om viktigheten av å ha profesjonelle rammer og kvalitet i arbeidet. Jeg oppfattet en større flyt i praten når hun snakket om disse temaene. Observasjonsloggene brukte jeg for å underbygge avgjørelsene om å velge bort noen tema for å framheve andre i arbeidet med å identifisere grunnforståelsen i hver lærers praksis. Temaet profesjonalitet var for eksempel det jeg forsto som mest framtredende i Ingses ytringer og refleksjoner om egen praksis, både i intervjuene, i uttalelser på møtene og i hennes praktiske arbeid med elevene:

Så det er akkurat som at vi opphever litt denne tradisjonelle lærer-elev-relasjonen. Det blir en teaterproduksjon. Med regissør, med produksjonsleder, med musikalsk leder... lærerne blir det, og ikke lærere, i den forstand. Og det har jeg tenkt litt på, at det også kanskje... det at lærerne er der med sin fagkompetanse på akkurat det området. (Intervju med Ingse)

I flere av undervisningssituasjonene observerte jeg at i det Ingse startet arbeidet med skuespillerne på scenen, la hun fra seg rollen som lærer til fordel for rollen som teaterinstruktør.

Fra observasjoner av Frodes undervisning identifiserte jeg lererrollen, fellesskap og mestring som sentrale handlinger. Følgende utdrag fra observasjonslogg kan eksemplifisere dette:

Frode sitter inne i orkesterbua sammen med bandet. Han sitter bakerst (bak de to trommisene) med manus på notestativet. Så mye som mulig har elevene selv ansvar for å telle opp og starte de ulike låtene på stikkord fra skuespillerne, men innimellom teller han opp for dem da det tydeligvis er vanskelig å finne riktig puls. Musikerne kommer med innspill til hva som kan gjøres for at ting skal fungere. Frode snur seg mot meg og sier: «Det er litt med balansen i hvor mye de kan blande seg, det tar jo tid. Men det er jo så viktig at de får ha meninger om saker og ting, de er veldig reflekterte.» (Fra observasjonslogg)

Gjennom identifisering av tema og videre reduksjon i antallet av disse, analyserte og utviklet jeg det jeg forstår som grunnforståelsen i hver enkelt lærers praksis. Resultatet av dette arbeidet vil jeg nå sammenfatte og presentere gjennom fire narrativer. Hvert narrativ er konstruert av meg som forsker, i samspill med empirien. Narrativene om Ingse og Frode er deskriptive narrativer som hovedsakelig er basert på konkrete enkeltobservasjoner i datamaterialet, mens Siri og Torhilds narrativer er skrevet i en mer abstrakt form, konstruert og sammensatt av uttalelser hentet fra både 
intervju- og observasjonsmaterialet. Jeg vil speile hvert narrativ i teori, og etterpå diskutere dem i dialog med hverandre og i lys av teori om praksisarkitekturer (Kemmis et al., 2014).

\section{Oppdagelser: Narrativer om de fire lærerne}

Lærerteamet i faget produksjon for scene ved Lillenes ungdomsskole består av fire lærere: Ingse, Frode, Siri og Torhild. Ingse har regiansvaret i musikkteaterproduksjonen og presenteres gjennom narrativet Teaterinstruktøren. Frode har det musikalske ansvaret og presenteres som Musikkpedagogen. Siri har overordnet administrativt ansvar for arbeidet, hennes narrativ har jeg kalt Produksjonslederen. Torhild er ansvarlig for sminke- og kostymegruppa og blir presentert som Kunstnersjelen.

\section{Narrativ 1: Teaterinstruktøren}

Ingse er akkurat ferdig med dagens oppvarming med elevgruppa. Hun kjenner at hun er påkoblet og klar. På øvingsplanen $i$ dag står scenen med møtet mellom «Peen» og «Den grønnkledde». De to er alene på scenen. Elevene som ikke deltar $i$ denne scenen sitter $i$ trappa og leser manus eller følger med på det som skjer. Peer og Den grønnkledde skal ri over scenen på en gris. Ingse ser at det er en utfordrende situasjon, det at de to tenåringene skal sitte tett bak hverandre. Det er fnising og latter. "Hvordan skal vi få til dette?» firer Peer. Ingse roper fra sidelinja: "Husk på at du er $i$ rolle. Det er ikke DU som gjør dette her!» Hun går energisk inn på scenen, beveger seg raskt rundt de to skuespillerne og gir klare, direkte beskjeder. Ingse vil ha energi $i$ uttrykket, det skal ligge flørt og romantikk i lufta. Hun visualiserer forelskelse med kroppsspråk på flere ulike måter og er direkte $i$ språket når hun instruerer Den grønnkledde: "Du er fandenivoldsk, kynisk og trollete. Du har bestemt deg for at du vil ha han. Kjenn på det og vis det på scenen!» Den grønnkledde spør: "Men klarer jeg det, da?» Ingse er kjapp i svaret: «Fa, det klarer du. Garantert. En million prosent sikkert!» Mor Aase og Solveig entrer scenen. Ingse roper: "Det er veldig bra! Men gjør det en gang til. Bruk rommet! Opp og ned $i$ stemmevolum. Bare prøv dere fram!» Hun er andpusten og svett når hun avslutter før pause: "For å sitere en teaterkollega:Vi leker ikke teater!» Hun har høye forventninger til elevene. De må tenke proft. Teater er knallhardt arbeid.

Grunnforståelsen i Ingses praksis forstår jeg å være at hun inntar rollen som profesjonell teaterinstruktør i skolen. Lærer-elev-forholdet byttes ut til fordel for regissørskuespiller-relasjonen. De «leker ikke teater», og hun setter høye krav til elevene om at de må ikle seg rollen som skuespillere med de krav det medfører av konsentrasjon og innlevelse i de ulike rollene. En kunstfaglærers spenninger mellom rollen som utøver og pedagog kan betegnes som et profesjonsdilemma. Angelo (2014) argumenterer for glidende overganger og styrken ved å reflektere og bevisstgjøre seg dette. I Ingses tilfelle forstår jeg det som at hun har tatt et tydelig og reflektert valg: I faget produksjon for scene er hun profesjonell teaterinstruktør framfor lærer, og dette kommer fram både i det hun sier, det hun gjør og måten hun relaterer til elever og lærere på. 


\section{Narrativ 2: Musikkpedagogen}

Det er fellesøving. Frode sitter bakerst $i$ orkesterbua. Han vil at elevene $i$ orkesteret skal styre seg selv, så han griper inn så lite som mulig. Han sitter der mest for å trygge dem. Det er rolig stemning $i$ bua. Håkon, en av gitaristene, er svart forsiktig. Han er flink til å spille, men trekker seg hele tiden unna situasjoner der han kan komme $i$ søkelyset, han vil helst gjemme seg inne $i$ mengden. På avslutningsscenen gir Ingse beskjed om at hun vil ha to av musikerne fram på scenen for å spille djembe, og det blir omrokkering $i$ bandbesetningen. Den ene gitaristen må spille bass, den andre piano, og nå er det bare Håkon igjen til å spille sologitar under applausmusikken. Det er han overhodet ikke interessert i. Frode utfordrer ham forsiktig, med glimt $i$ øyet: "Vi kan ikke bare ha komp, vi må ha en melodilignende solo. Og se deg rundt da, ser du noen andre her som kan gjøre det?» Frode trekker seg tilbake. Avventende, nynner på sangen. Bassisten setter $i$ gang kompet. Håkon leter seg fram på gitaren og etter et par minutter spiller han solo som om han ikke har gjort annet. Etter soloen går Frode bort til ham, klemmer ham på skulderen og nikker bekreftende. Disse øyeblikkene av mestring.

Frode søker å motivere elevene gjennom å skape trygge rammer og gode relasjoner til elevene. Frode har en pedagogisk tilnærming til det kunstfaglige arbeidet og har som mål å tilrettelegge for mestring. Han sier at han er opptatt av det, han gjør det i sine handlinger og han relaterer seg på en måte til elevene som gir rom for utfoldelse i trygge rammer. Sørensen \& Austring (2010) skriver om lærerens betydning i estetiske læreprosesser, og med en psykologisk tilnærming eksemplifiserer de dette gjennom psykologen Winnicotts teori om det potensielle rom. I det potensielle rom kan mennesket gjennom lek og kunst utvikle forståelse om seg selv, de andre og den verden det er en del av, i et kreativt frirom mellom en indre subjektiv verden og en ytre objektiv verden. For at kreativiteten i det potensielle rom skal utvikles optimalt er det vesentlig med en atmosfære av konsekvensfrihet (Sørensen \& Austring, 2010). Da er det er en forutsetning at pedagogen evner å legge til rette for et godt læringsmiljø, trygge rammer for undervisning og gode relasjoner mellom lærer og elev. Dette finner jeg som grunnforståelsen i Frodes praksis. I den konkrete undervisningssituasjonen i narrativet vises et gyllent øyeblikk der læreren forløser et artistisk potensial hos eleven i det potensielle rom.

\section{Narrativ 3: Produksjonslederen}

Det er møte mellom rektor og lcererteamet om innspurten fram mot premiereuka. Siri tenker på alt arbeidet som står igjen. Det koker $i$ hodet og hun skjønner ikke hvordan de skal komme $i$ mål. Rektor spør om de er $i$ rute, og hun hører $i$ det fjerne at Frode svarer et eller annet. Så spisser hun ørene og løfter blikket. Rektor sier at hun ikke har fått en eneste kommentar fra de andre lererne om at produksjon for scene fär for mye ressurser $i$ form av tid og penger $i$ år. Hun sier at det er viktig for henne at denne oppsetningen ikke bare er produksjon for scene sin, men at hele skolen skal ha et eierforhold til den. Siri kjenner at hun blir varm inni seg. Så mye som har skjedd siden starten på faget for fire år siden. Det første året gjorde tre larere alle oppgavene tilknyttet produksjonen, alt fra à snekre kulisser og sy kostymer til 
å lage mat. Siden den gang har Siri stått $i$ spissen for å bygge en solid organisasjonsstruktur. Skolen har opprettet et eget teaterlag, Torhild med kompetanse $i$ sminke og kostyme har kommet til i lererteamet, og nå er det foreldrene som lager mat til elevene, serverer, rydder og står vakt under forestillingene. Før var mange av larerkollegene negative til at skolen og elevene brukte så mye tid og ressurser på faget, og delte ut omfattende arbeidsplaner til produksjon for scene-elevene den siste øvingsuka før forestillingsperioden. Nå opplever hun respekt og forståelse for at produksjon for scene er seriøst arbeid og at det krever så mye tid og energi at elevene ikke har kapasitet til så mye annet skolearbeid $i$ perioden før premiere. Siri kjenner seg stolt. Hun vet at de har kommet langt $i$ arbeidet for fagets status på skolen.

Grunnforståelsen i Siris praksis forstår jeg som organisator og strategisk tilrettelegger. Siri er en lærer som virkelig brenner for produksjon for scene. For at elevene skal oppnå maksimalt læringsutbytte vet Siri at de materiell-økonomiske forholdene må tilrettelegges slik at de muliggjør framfor å begrense fagets praksis. I en studie basert på en landsomfattende spørreskjemaundersøkelse blant lærere som underviser i faget, synliggjøres det at lærerne opplever produksjon for scene som et krevende fag å undervise i, særlig på grunn av dårlig tilrettelagte rammefaktorer som tid og materielle ressurser (Kolaas \& Angelo, 2021). I arbeidet med å bygge faget produksjon for scene ved Lillenes ungdomsskole, bringer Siri sin ekspertise innen administrativt teaterarbeid inn i skolen ved å bygge opp en profesjonell teaterorganisasjon innad i skolen. Elstad et al. (2014, s. 30) hevder at det fortsatt finnes lite kunnskap om hvordan lærere drar nytte av kunnskap som finnes i kollegiet og i ekspertmiljøer utenfor skolen. I denne studien ser vi at Siri drar nytte av sin kompetanse i organisasjonsarbeid til å bygge profesjonelle rammer for musikkteatervirksomhet innad i skolen. Dette muliggjør gode produksjoner, og kvaliteten og seriøsiteten i arbeidet blir videre argumenter for fagets høye status i kollegiet.

\section{Narrativ 4: Kunstnersjelen}

Torhild finner fram blokka si. Den hun alltid har med seg for å notere idéer som dukker opp $i$ hodet hennes. Hun blar fort gjennom notatene fra samtaler med Ingse om de ulike rollene, og om stemningen og atmosferen $i$ de ulike scenene. Hun åpner døra inn til kunst og håndverk-rommet. Elevene $i$ kostymegruppa sitter klare ved hver sin symaskin, med forventning $i$ blikket. Det er oppstart av arbeidet med magedanskostymene. Torhild ser klart for seg hvordan hun selv ville designet draktene, men nå er det elevenes kunstneriske uttrykk som skal $i$ fokus. "Magedansscenen...", begynner hun. Hun lar ordet henge i lufta. Gir rom for assosiasjonene. "Vi må leve oss inn i rollekarakterene og situasjonen rundt. Hvor er vi? Hvordan ser det ut rundt oss? Hvordan lukter det? Hvilken stemning skal vi formidle? Feg ser for meg... India?" "Nei, det er jo ikke i India», fniser en elev. Og så er de i gang. Det skal vare eksotisk. Farger. Puffermer. Plysj. Skjørt. Hvor mye hud kan vises? Hvor er saksa? Elevene får ansvar for hvert sitt kostyme. Torhild vil at de skal kjenne at det er de selv som har skapt det. Hun lar dem holde på. Lar dem arbeide mest mulig fritt, veileder der det trengs. Det viktige er ikke om glidelåsen sys $i$ med dobbel eller enkel søm, men at elevene får skape sine egne mønstre, 
sine egne kunstneriske uttrykk. Hun gleder seg til à se elevenes begeistring over de ferdige kostymene på skuespillerne, på scenen. Gleder seg til å høre dem hviske til sideeleven at «den drakten er det jeg som har laget». Hun har sett det så mange ganger for, og når de kommer dit, da vet hun at elevene har fått et eierforhold til det de har skapt.

Torhild er en skapende kunstner. Hun bringer kunstneridentiteten med seg inn i arbeidet med faget, og dette kunstnerblikket vil hun inspirere elevene med. I profesjonsdilemmaet mellom kunster eller lærer forstår jeg Torhild først og fremst som skapende kunstner (Angelo, 2014), men hun tenker samtidig pedagogisk om hvordan hun skal nå inn til elevene. Hun gir rom for læring gjennom følelser, sanselighet og kropp (Østern et al., 2019) og søker innganger til hvordan hun skal tenne elevenes skaperlyst og skaperglede gjennom å gi dem en impuls for å starte en kreativ prosess (Ross, 1978). Det er denne impulsen Torhild søker når hun forestiller seg situasjonen og stemningen rundt rollekarakterene det skal sys kostymer til. Torhild er en lærer som gir elevene stor kunstnerisk frihet, både $\mathrm{i}$ valget av materialene de skal bruke for å uttrykke seg, og i formen der hun er opptatt av at elevene skal ha sitt eget personlige og kunstneriske uttrykk.

\section{Diskusjon}

Deltakerne i et praksisfellesskap møter hverandre i sosiale rom som språk, rom og tid i den materielle verden og i sosiale forhold, skriver Kemmis et al. (2014). Det er disse rommene som muliggiør praksisens ytringer, handlinger og relasjoner. I diskusjonen vil jeg vise hvordan det profesjonelle kunnskapslandskapet (Craig, 2007) ved Lillenes ungdomsskole formes av språket og de materielle og sosiale forholdene lærerne er omgitt av, og en del av.

Tre av fire lærere i denne studien har bakgrunn fra teaterverden, og praksisens ytringer har tydelige spor derfra. Ingses klare krav til profesjonalitet har satt en tydelig signatur på lærernes felles språk. I alle ledd, både i produksjonsmøter, i møter med ledelsen og i undervisningssituasjoner med elevene, kommuniseres det tydelig at det settes høye krav til alle om at produksjonen skal være så profesjonell som mulig. Dette gjelder på alle de scenekunstfaglige områdene; sang, musikk, regi, koreografi, scenografi, sminke, kostyme, lys og lyd. Ingses utsagn «Vi leker ikke teater!» kan representere denne grunnforståelsen i det profesjonelle kunnskapslandskapet. Samtidig farger Frodes pedagogiske grunnforståelse om fellesskap og mestringsfølelse lærernes ytringer. Dette kommer til syne i undervisningssituasjonene mellom lærere og elever, der artikuleringen av profesjonalitetskravet uttrykkes med omtanke for elevene og pedagogisk tilsnitt. Teaterfaglig profesjonalitet og pedagogisk tenkning om fellesskap og mestring synes å samvirke i språkliggjøringen av lærernes praksis.

Praksisens handlinger muliggiøres av rom og tid i den materielle verden (Kemmis et al., 2014). Siri administrerer produksjonsarbeidet i forhold til tid, rom og økonomi, i tett samarbeid med ledelsen. De materielle forholdene for lærerne ved Lillenes 
ungdomsskole er godt tilrettelagt fra ledelsens side. Lærerne og elevene har nok rom tilgjengelig til at de kan jobbe i grupper, og lærertettheten muliggiør nær veiledning av elevene i det innledende arbeidet fram mot fellesøvingsperioden. Tilgjengeligheten av rom og tid gjør at Ingse kan jobbe med skuespillerne, samtidig som at Frode kan jobbe med musikerne og Torhild kan konsentrere seg om sminke og kostyme. Muligheten til bruk av tid ut over ordinær undervisningstid, de økonomiske forholdene og tilknytningen til teaterorganisasjonen Frilynt, muliggiør kravet om profesjonalitet og kvalitet innenfor alle de scenekunstfaglige områdene. Praksisens handlinger foregår i tid og rom som ses som nødvendig og forsvarlig ut fra faglige premisser i arbeid med musikkteater, noe som giør at denne delen av praksisarkitekturen muliggiør framfor å begrense praksisen.

De sosiale forholdene setter rammer for praksisens relasjoner. I dette tilfellet gjelder dette lærernes forhold og relasjon til hverandre, ledelsen, andre kolleger og ikke minst til kunst- og musikkteaterverden utenfor skolens kontekst. I praksisarkitekturteorien forklares dette gjennom dikotomien makt og solidaritet, ved å vise hvordan de sosiale forholdene og ulike relasjoner kan prege praksiser (Kemmis et al., 2014). Et funn i denne studien er at profesjonaliteten i lærernes arbeid i hovedsak kommer fra lærernes relasjon til den profesjonelle kunst- og musikkteaterverden utenfor skolen. Dette synes å gi lærerne en form for makt som igjen åpner for respekt og solidaritetstenkning fra kolleger og ledelse. Videre gir det faget troverdighet og høy status på skolen, og legger grunnlag for gode arbeidsforhold for lærerne i form av ressurser, tilrettelegging og respekt fra kolleger i andre fag. Dette gjelder ikke minst i relasjonen til ledelsen ved skolen. Støtten fra ledelsen har avgiørende betydning for arbeidsvilkårene og praksisarkitekturene. Betydningen av skolens ledelse i etableringen av såkalte profesjonelle læringsfellesskap er tidligere framhevet, og Elstad et al. (2014) hevder at skolens ledelse har et spesielt ansvar for å tilrettelegge for etablering av læring gjennom profesjonelle læringsfellesskap, både med tanke på tid og ressurser. De viser også til at å hente inn ekspertkunnskap utenfra kan være med på å styrke læringskulturene i skolen (Elstad et al., 2014). I denne studien er det et vesentlig poeng at den kunstfaglige ekspertisen $i$ hovedsak ikke hentes utenfra, men at den allerede finnes $i$ kollegiet gjennom relasjonen til den profesjonelle og frivillige kunst og kulturverden utenfor skolen, og at utnyttelse av denne kunnskapen har stor betydning for fagets status. Praksisens relasjoner framstår dermed som muliggjørende framfor begrensende i konstruksjonen av praksisarkitekturene.

\section{Det profesjonelle kunnskapslandskapet ved Lillenes ungdomsskole}

Det profesjonelle kunnskapslandskapet i faget produksjon for scene ved Lillenes ungdomsskole skapes og defineres av de fire lærernes individuelle praksiser, som i hovedsak er formet av den kunstfaglige ekspertisen de har med seg fra det profesjonelle og frivillige kunst- og kulturfeltet utenfor skolen. Gjennom å diskutere narrativene om de fire lærerne i dialog med hverandre og i lys av teori om praksisarkitekturer 
(Kemmis et al., 2014), finner jeg at lærernes ulike praksiser samvirker til det Craig (2007) omtaler som et profesjonelt kunnskapslandskap. Det profesjonelle kunnskapslandskapet er formet som en kollektiv enhet, både mellommenneskelig og faglig, og er skapt av relasjoner mellom mennesker, institusjoner og fysiske rammefaktorer. Grunnforståelsen i det profesjonelle kunnskapslandskapet er profesjonalitet og kvalitet i det kunstfaglige arbeidet. Dette operasjonaliseres gjennom at skolen transformeres til en profesjonell musikkteaterarena, der for eksempel lærer-elev-forholdet byttes ut til fordel for regissør-skuespiller-relasjonen. Pedagogisk tenkning om felleskap og mestring er også en viktig del av kunnskapslandskapet.

Profesjonaliteten og kvaliteten i arbeidet med faget fører til respekt fra kolleger og ledelse, noe som gir faget høy status i skolen. Dette legger videre føringer for at faget får gode arbeidsvilkår, noe som muliggjør profesjonalitet og kvalitet i produksjonene som skapes. Slik veves dette sammen og viser hvordan fagets praksisarkitekturer er komponert ved skolen, i relasjon til profesjonelle kunst- og kulturinstitusjoner lokalt og nasjonalt.

\section{Epilog}

Siste forestilling $i$ produksjon for scene ved Lillenes ungdomsskole for $i$ år er akkurat over. Siri går bak scenen for å takke deltakerne. Hun hører applausen fra et begeistret publikum bak seg. En av guttene $i$ bandet står med hodet $i$ hendene. Han hikster. Tårene triller og han klarer ikke à stoppe. Siri tar omkring ham: "Er du lei deg?» «fa, jeg er lei meg», sier han. "Lei meg for at vi er ferdig. Feg vil ikke at det skal vaere ferdig nå. Nå gleder jeg meg bare til å starte i tiende. Da skal jeg velge produksjon for scene igjen."

\section{Forfatteromtale}

Solveig Salthammer Kolaas er doktorgradsstipendiat, ved fakultet for lærerutdanning, kunst- og kulturfag. Hun arbeider med en artikkelbasert avhandling med tittelen «Samkunst som meningsskapende tilnærming - en mixed methods studie om valgfaget produksjon for scene».

\section{Litteratur}

Angelo, E. (2014). Kunstner eller lærer? Et illustrerende profesjonsdilemma i det musikk- og kunstpedagogiske landskapet. I E. Angelo \& S. Kalsnes (Red.), Kunstner eller lerer? Profesjonsdilemmaer $i$ musikk- og kunstpedagogisk utdanning (s. 21-41). Cappelen Damm Akademisk.

Bobetsky, V. V. (2008). The magic of middle school musicals: Inspire your students to learn, grow, and succeed. R\&L Education.

Clandinin, J. (2015). Stories to live by on the professional knowledge landscape. Waikato fournal of Education. Special 20 th Anniversary Collection 2015, 183-193. https://doi.org/10.15663/wje.v5i0.403

Craig, C. (2007). Story constellations: A narrative approach to contextualizing teachers' knowledge of school reform. Teaching and Teacher Education, 23(2), 173-188. https://doi.org/10.1016/j.tate.2006.04.014

Dæhlen, M. \& Eriksen, I. M. (2015). "Det tenner en gnist». Evaluering av valgfagene på ungdomstrinnet (NOVA rapport nr 2/15). Høgskolen i Oslo og Akershus. 
Edberg, L. (2013). Crossing borders. Perspectives on learning in a school musical project. I S.-E. Holgersen, E. Georgii-Hemming, S. G. Nielsen \& L. Väkevä (Red.), Nordisk musikkpedagogisk forskning årbok 14 (s. 181-194). Norges musikkhøgskole.

Edberg, L. (2019). Skolmusikalen: Om möten, makt och musiki två skolmusikalprojekti årskurs ni [Doktoravhandling] . Umeå universitet.

Elstad, E., Helstad, K. \& Mausethagen, S. (2014). Profesjonsutvikling i skolen. I E. Elstad \& K. Helstad (Red.), Profesjonsutvikling $i$ skolen (s. 17-38). Universitetsforlaget.

Emstad, A. M. \& Birkeland, I. K. (2020). Lerende ledelse. Universitetsforlaget.

Flyvbjerg, B. (2010). Fem misforståelser om casestudiet. I S. Brinkmann \& L. Tanggaard (Red.), Kvalitative metoder - en grundbog (s. 463-487). Hans Reitzels Forlag.

Hargreaves, A. (2000). Four ages of professionalism and professional learning. Teachers and teaching: Theory and practice, 6(2), 151-182. https://doi.org/10.1080/713698714

Helstad, K. (2014). Kunnskapsutvikling gjennom samtaler i tverrfaglige læringsfellesskap. I E. Elstad \& K. Helstad (Red.), Profesjonsutvikling $i$ skolen (s. 134-151). Universitetsforlaget.

Josselson, R. (2011). Narrative research: Constructing, deconstructing and reconstructing story. I F. J. Wertz, K. Charmaz, L. M. McMullen, R. Josselson, R. Anderson \& E. McSpadden (Red.), Five ways of doing qualitative analysis. Phenomenological psychology, grounded theory, discourse analysis, narrative research, and intuitive inquiry (s. 224-242). Guilford.

Kemmis, S., Wilkinson, J., Edwards-Groves, C., Hardy, I., Grootenboer, P. \& Bristol, L. (2014). Changing practices, changing education. Springer.

Kolaas, S. S. \& Angelo, E. (2021). Samkunstlig lcering for selve livet: Om danning og livsmestring $i$ valgfaget produksjon for scene [Sendt utgiver, under vurdering]. Fakultet for lærerutdanning og kunst- og kulturfag, Nord universitet.

Kolaas, S. S. \& Knigge, J. (under utgivelse). Det store bildet - en kartlegging av faget Sal og scene i Norge i 2019. I B.-T. Bandlien, E. Angelo, I. O. Olaussen \& M. A. Letnes (Red.), Arts education: Collaboration, quality and tensions. Cappelen Damm Akademisk.

Kunnskapsdepartementet. (2017). Verdier og prinsipper for grunnopplaringen - overordnet del av lareplanverket. Regjeringen. https://www.regjeringen.no/no/dokumenter/verdier-og-prinsipper-for-grunnopplaringen/ id2570003/

Kunnskapsdepartementet. (2019, 18. november). Fornyer skolens innhold: Nye lereplaner skal gi elevene tid til mer fordypning [Pressemelding]. Regjeringen. https:/www.regjeringen.no/no/aktuelt/nye-lareplaner-skal-gielevene-tid-til-mer-fordypning/id2678138/

Kvale, S. \& Brinkmann, S. (2015). Det kvalitative forskningsintervju. Gyldendal.

Postholm, M. B. (2010). Kvalitativ metode. En innføring med fokus på fenomenologi, etnografi og kasusstudier (2. utg). Universitetsforlaget.

Riessman, C. K. (2005). Narrative analysis. I N. Kelly, C. Horrocks, K. Milnes, B. Roberts \& D. Robinson (Red.), Narrative, memory $\&$ everyday life (s. 1-7). University of Huddersfield.

Riessman, C. K. (2008). Narrative methods for the human sciences. Sage Publications.

Ross, M. (1978). The creative arts. Heinemann.

Rønning, O. S. (2019). Sal og scene: En studie av elevers perspektiv på praktisk-estetisk undervisning [Masteroppgave]. Nord universitet.

Stake, R. E. (1995). The art of case study research. Sage Publication.

Sørensen, M. \& Austring, B. D. (2010). Mot et læringsorientert estetikkbegrep. I G. Salvesen \& J. H. Sætre (Red.), Allmenn musikkundervisning - perspektiver på praksis (s. 39-53). Gyldendal Akademisk.

Utdanningsdirektoratet. (2012a). Produksjon av varer og tjenester (VAL0007). https://www.udir.no/k106/ VAL0007/

Utdanningsdirektoratet. (2012b). Lareplan $i$ valgfaget sal og scene (SOS1-01). https://www.udir.no/k106/ SOS1-01/

Utdanningsdirektoratet. (2020). Lareplan $i$ valgfaget produksjon for scene (SOS01-02). https://www.udir.no/lk20/ sos $01-02$

Østern, A.-L. (2018). Kunstneres personlige kunnskapslandskap. Fortellingssammenstilling som strategi i analyse av kunstneres utemmede fortellinger om begynnelser på skapende prosesser. Fournal for Research in Arts and Sports Education, 2(1), 139-153. https://doi.org/10.23865/jased.v2.1132

Østern, T. P., Dahl, T., Strømme, A., Petersen, J. A., Østern, A.-L. \& Selander, S. (2019). Dybdelcering - en flerfaglig, relasjonell og skapende tilncerming. Universitetsforlaget. 